\title{
Heamatological Characteristics of Young Rabbits fed a mixture of Alchornea cordifolia/Pawpaw leaf meal.
}

\author{
M.B. Nodu, M. Okpeku and A.E. Abezi \\ Department of Livestock Production Technology, Niger Delta University, Wilberforce Island Bayelsa State, \\ Nigeria.
}

\begin{abstract}
This study was conducted to investigate the effect of Alchornea cordifolia leaf meal (ACLM)/Pawpaw leaf meal (PLM) on the haematology of young rabbits aged 12-14 wks. The study involved twenty four (24) young rabbits of both sexes and of mixed breeds randomly allocated to four treatment groups of two replicates per treatment with three rabbits in each replicate. The treatment groups were designated as $T_{1}, T_{2}, T_{3}$ and $T_{4}$, for rabbits fed control meal of concentrate and forage, rabbits fed Alchornea cordifolia leaf meal (ACLM), rabbits fed pawpaw leaf meal (PLM)and rabbits fed a mixture of ACLM and PLM at a ratio of 50:50, respectively. Cool clean drinking water was provided ad libitum to all the treatment groups while the experiment lasted. The experiment lasted for eight weeks at the end of which blood samples were collected from the animals on treatment basis and haematological parameters examined. Haematological parameters examined included Haemaglobin (Hb), Packed cell volume (PVC), Red blood cell (RBC), White blood cell (WBC), Neutrophils, Lymphocytes, Eosinophils, Monocytes and Basophils. In these parameters considered, Pawpaw leaf meal showed a significant higher values in $\mathrm{Hb}$ (13.35 \pm 0.05$), P V C(41.50 \pm 0.05)$ RBC (6.08 \pm $0.09)$ and WBC $(9.15 \pm 1.55)$ than the control group and other treatment groups. There were however no significant differences $(P>0.05)$ in virtually all these parameters in the control group $\left(T_{1}\right)$ and the group fed ACLM and PLM mixture $\left(T_{4}\right)$. Therefore, it could be considered that feeding rabbits with Alchornea cordifolia leaf meal, pawpaw leaf meal and their mixture at ratio of 50:50 has no adverse effect on the blood (haematology) of the animals.

Keywords: Haematology, Alchornae cordifolia leaf meal, Pawpaw leaf meal, Red blood cell, Haemoglobin, white blood cell, packed cell volume.
\end{abstract}

\section{Introduction}

Livestock production is a vital component of the Agricultural Industry and much effort is being directed towards improving this sector. One of these efforts is sourcing for feeds at minimal cost with minimal consequential effects on the animals' performance. Yet, the challenges confronting the industry keep taking new dimensions. For instance, the high cost of animal feeds precipitated by ever increasing cost of feed ingredients, especially protein sources has resulted in declining productivity by animal production in most parts of the world especially developing nations. This scenario has caused the price of animal products to rise beyond the purchasing ability of the average citizen and consequently reduced animal protein intake in their diets. Several animal species both farm animals and game are used to meet this high demand for animal protein. But given the central importance of rabbit among other livestock in bridging the animal protein gap, it therefore calls for attention to be shifted towards rabbit production. Rabbits are highly prolific animals capable of increasing the animal protein intake of Africans. Also, their reputation for past growth, short gestation period, early maturity, ease of management and their small sizes make them affordable (Chestwort, 2002). Rabbits have unique feeding characteristics and thrive well on forages which is an added advantage. It becomes very necessary to exploit biological values that can help supplement the costly conventional protein sources. Leaf meal supplementations are usually included into feeding regimen of animals as means of reducing high cost of conventional protein sources and improve profit margin.

Pawpaw (Carica papaya) is a plant native to tropical America but it is popular in the tropics an subtropics because of its easy cultivation, rapid growth rate, quick economic returns and adaptation to diverse soils and climate (Cambell, 1984). The fruits are high in vitamins (A, B1, B2 and C) and mineral (Ca, K, P, Fe), low in Sodium, fat and calories and contains practically no starch (Yadava et. al., 1990). Pawpaw leaves are rich source of proteolytic enzymes papain and chymopapain (Poulter and Caygill, 1985). These enzymes have protein digesting properties and are useful in controlling digestive problems and intestine worms as well as cleansing the digestive tract (Burkhill, 1985: Poulter and Caygill, 1985).

Alcornia cordifolia commonly called Christmas bush is a tropical browse plant that forms a good proportion of the evergreen vegetation of the humid tropical zone of Southern Nigeria. It produces large quantities of foliage and seeds that are consumed in the field by gorillas and chimpanzees (Sugiyama and Koman, 1992). Christmas bush is commonly used in zero-grazing by rural livestock farmers for feeding of small 
ruminants and also used by local inhabitants for cure of many ailments/diseases in man (Okoli et al, 2002; Iwu 1995).

Haematological values are widely used to determine the systemic relationships and physiological/pathological adaptation in animals. This includes evaluation of good health conditions and diagnosis of various types of animal diseases (Shah et al., 2007). The choice of these plants (Carica papaya and Alcornia cordifolia) is based on the limited knowledge about them especially as it relates to the haematological characteristics in animals fed these plants. Such knowledge being exploited could be channeled to enhancing animal health and subsequent improvement in the livestock industry. This study was therefore designed to ascertain the effect of feeding the leaf meals of these two tropical plants (Pawpaw and Christmas bush) on the haematological characteristics of growing rabbits.

\section{Material and Methods}

This study was conducted using twenty four (24) semi-adult mixed breeds rabbits of both sexes weighing between $1.5-3.5 \mathrm{~kg}$. These animals were randomly divided into four groups of six (6) rabbits per group making the four treatments. Each group of 6 rabbits were further divided into 2 sub-groups of 3 animals each in the replicates per group. Animals in each replicate were housed in a separate single-tier hutch constructed with wooden frame and wire mesh which permitted adequate ventilation. Prior to commencement of the experiment, all animals were given same feed, water and medication.

\section{The treatment groups are as follows:}

$\mathrm{T}_{1}$ : Control group fed concentrate and forage

$\mathrm{T}_{2}$ : Group fed Alcornea cordifolia leaf meal (ACLM) and concentrate

$\mathrm{T}_{3}$ : Group fed Pawpaw leaf meal (PLM) and concentrate

$\mathrm{T}_{4}$ : Group fed mixture of Pawpaw leaf meal and Cordifolia Alcornea leaf meal at (50:50) with concentrate.

A measured quantity of $200 \mathrm{~g}$ of the leaf meals was fed to rabbits in each of the hutches i.e. per replicate. The Alcornea cordifolia leaf meal (ACLM) and Pawpaw leaf meal (PLM) were processed by harvesting the leaves from the plants and chopped into small bits. They were then sun dried until crispy to touch while retaining their greenish colouration. These experimental diets were fed to the rabbits in the stated quantities in the morning and them concentrate feed (growers mash) as recommended by Ibeawuchi and Fajuyitan (1986) is fed to then in the evening also at a restricted quantity of $50 \mathrm{~g}$. Pure clean water was administered $\underline{a d} \underline{\text { libitum }}$ to the rabbits. The experiment lasted for eight weeks after two weeks of pre-experimental period.

At the end of the feeding period, blood samples were collected from two rabbits per replicate for haematological analysis. The blood samples were collected from the rabbits' external ear vein using sterilized disposable syringe and needle. The blood was collected in labelled Ethylene Diamine Tetra acetic (ETDA) bottles (ETDA serving as anticoagulant). On collection of the blood samples, the bottles were immediately capped and the content mixed gently by repeated inversion for about one minute. Within one hour, the blood samples were analysed for the following haematological characteristics: Pack cell volume (PVC), Red blood cell, (RBC), White blood cell (WBC), Haemoglobin (Hb), Neutrophils (N), Eosinophils (E), Lymphocytes (L), Monocytes (M) and Basophils (B) using the appropriate methods for each parameter.

Data collected were analysed using Analysis of Variance (ANOVA) and descriptive Statistics of SPSS for windows (version 16) computer software. Difference between means were separated by Duncan Multiple Range Test (DMRT) (Duncan 1955).

\section{Results and Discussion}

Results: The results for the proximate analysis of the diets fed to the different treatment groups are presented in tables 1, 2 and 3 below. Table 1 shows the proximate analysis for the commercial growers mash fed to the control group $\left(\mathrm{T}_{1}\right)$. The diet was found to be rich in crude protein, crude fibre, ash, fat and two essential amino acids required by rabbits which are lysine and methionine. This diet composition meets the nutrient requirements as reported by Ibeawuchi and Fajuyitan (1986).

Table 1: Proximate analysis of growers mash as control diet

\begin{tabular}{ll}
\hline Fraction & Composition \\
\hline Energy $(\mathrm{Cal} / \mathrm{kg})$ & 25.11 \\
Crude protein $(\%)$ & 15.10 \\
Calcium $(\%)$ & 1.00 \\
Phosphorus $(\%)$ & 0.43 \\
Fibre $(\%)$ & 5.78 \\
Lysine $(\%)$ & 0.90 \\
Methionine $(\%)$ & 0.41 \\
Fat $(\%)$ & 3.34 \\
\hline
\end{tabular}


The results of the proximate composition of Alcornea cordifolia which served as the diet for animals in treatment $2\left(\mathrm{~T}_{2}\right)$ is presented in Table 2. The Alcornea cordifolia leaf meal (ACLM) shows a fairly rich crude protein content of $12.66 \%$, ash $(8.14 \%)$, ether extract $(8.30 \%)$, dry matter $(17.75 \%)$ and low crude fibre of $2.26 \%$.

Table 2: Proximate composition of Alchornea Cordifolia leaf meal

\begin{tabular}{ll} 
(ACLM) & Composition (\%) \\
\hline Fraction & 17.75 \\
\hline Dry matter & 12.66 \\
Crude protein & 2.26 \\
Crude fibre & 8.30 \\
Ether extract & 8.14 \\
Ash & \\
\hline
\end{tabular}

Table 3 is a presentation of the proximate composition of the Pawpaw leaf meal (PLM) fed to animals in treatment $3\left(\mathrm{~T}_{3}\right)$. The result indicated a low level crude protein $(8.85 \%)$, crude fibre $(1.85 \%)$, ether extract $(8.24 \%)$ ash $(6.38 \%)$ and a high dry matter of $22.10 \%$.

Table 3: Proximate analysis of Pawpaw leaf meal (PLM) on \% DM basis.

\begin{tabular}{ll}
\hline Fraction & Composition (\%) \\
\hline Dry matter & 22.10 \\
Crude protein & 8.85 \\
Crude fibre & 1.85 \\
Ether extract & 6.24 \\
Ash & 6.38 \\
\hline
\end{tabular}

Table 4 shows the results of the haematological components of the young rabbits fed the control diet (Growers mash) in treatment $1\left(\mathrm{~T}_{1}\right)$, Alchornea cordifolia leaf meal (ACLM) in treatment $2\left(\mathrm{~T}_{2}\right)$ Pawpaw leaf meal (PLM) in treatment $3\left(\mathrm{~T}_{3}\right)$ and animals in treatment $4\left(\mathrm{~T}_{4}\right)$, fed a mixture of ACLM and PLM on a 50:50 ratio. The following parameters (blood components) were considered for their haematological values. These are Haemoglobin ( $\mathrm{Hb}$ ), packed cell volume (PVC), Red Blood Cell (RBC), White Blood Cell (WBC), Neutrophils, Lymphocytes, Eosinophils, Monocytes and Basophils.

The results indicated lowest value $(10.00 \pm 0.00)$ for $\mathrm{Hb}$ in the animals fed Alchornia leaf meal (ACLM) in treatment $2\left(\mathrm{~T}_{2}\right)$ and the highest value of $13.35 \pm 0.05$ in animals fed Pawpaw leaf meal (PLM) in $\mathrm{T}_{3}$. Animals in the control group and those in $\mathrm{T}_{4}$ (mixture of PLM and ACLM) had virtually same value for $\mathrm{Hb}$. Packed cell volume (PVC) was observed to be lowest in animals fed ACLM and the highest score of $41.50 \pm$ 0.50. Similar trend was observed among the treatments in the values for Red Blood Cell (RBC) and White Blood Cell (WBC). The results indicated that there was however no significant difference $(\mathrm{P}>0.05)$ among the various treatments in the values recorded for Neutrophils, Lymphocytes and Monocytes. There was also significant difference $(\mathrm{P}>0.05)$ in the values in $\mathrm{T}_{2}(4.50 \pm 0.50)$ and lowest value of same score $(3.00 \pm 0.00)$ in $\mathrm{T}_{3}$ and $\mathrm{T}_{4}$. Only treatment $\mathrm{T}_{4}(\mathrm{ACLM})$ indicated a score of $1.00 \pm 0.00$ for Basophils. Other treatments including the control showed negative results.

Table 4: Haematological components of young rabbits fed Alchornea cordifolia leaf meal and Pawpaw leaf meal.

\begin{tabular}{lllll}
\multicolumn{4}{l}{ Table 4: Haematological components of young rabbits fed Alchornea cordifolia leaf meal and Pawpaw leaf meal. } \\
\hline Treatments/Parameters & $\mathrm{T}_{1}($ Control) & $\mathrm{T}_{2}(\mathrm{ACLM})$ & $\mathrm{T}_{3}(\mathrm{PLM})$ & $\mathrm{T}_{4}(\mathrm{ACLM}+\mathrm{PLM})$ \\
\hline Haemoglobin $(\mathrm{Hb}) \mathrm{g} / \mathrm{dl}$ & $12.95 \pm 0.35^{\mathrm{bc}}$ & $10.00 \pm 0.00^{\mathrm{a}}$ & $13.35 \pm 0.05^{\mathrm{c}}$ & $12.55 \pm 0.05^{\mathrm{b}}$ \\
Packed Cell Volume(PVC)\% & $39.00 \pm 1.00^{\mathrm{b}}$ & $30.00 \pm 0.00^{\mathrm{a}}$ & $14.50 \pm 0.05^{\mathrm{c}}$ & $37.50 \pm 0.05^{\mathrm{b}}$ \\
Red Blood Cell (RBC)X 10 $/ \mathrm{L}$ & $5.65 \pm 0.12^{\mathrm{b}}$ & $4.60 \pm 0.35^{\mathrm{a}}$ & $6.08 \pm 0.09^{\mathrm{c}}$ & $5.47 \pm 0.07^{\mathrm{b}}$ \\
White Blood Cell (WBC)x 10 $/ \mathrm{L}$ & $7.05 \pm 0.55^{\mathrm{a}}$ & $3.90 \pm 1.60^{\mathrm{a}}$ & $9.15 \pm 1.55^{\mathrm{b}}$ & $7.95 \pm 0.95^{\mathrm{ab}}$ \\
Neutrophils \% & $20.50 \pm 0.50^{\mathrm{a}}$ & $26.50 \pm 3.50^{\mathrm{a}}$ & $14.00 \pm 9.00^{\mathrm{a}}$ & $20.00 \pm 2.00^{\mathrm{a}}$ \\
Lymphocytes \% & $74.00 \pm 1.00^{\mathrm{a}}$ & $65.00 \pm 5.00^{\mathrm{a}}$ & $80.00 \pm 11.00^{\mathrm{a}}$ & $74.50 \pm 2.50^{\mathrm{a}}$ \\
Eosinophils \% & $3.50 \pm 0.50^{\mathrm{ab}}$ & $4.50 \pm 0.50^{\mathrm{b}}$ & $3.00 \pm 0.00^{\mathrm{a}}$ & $3.00 \pm 0.00^{\mathrm{a}}$ \\
Monocytes \% & $2.00 \pm 1.00^{\mathrm{a}}$ & $3.00 \pm 1.00^{\mathrm{a}}$ & $2.00 \pm 1.00^{\mathrm{a}}$ & $2.50 \pm 0.50^{\mathrm{a}}$ \\
Basophils \% & $0.00 \pm 0.00$ & $1.00 \pm 0.00$ & $0.00 \pm 0.00$ & $0.00 \pm 0.00$ \\
\hline
\end{tabular}

\section{Discussion:}

Blood is often considered as life in animals and it is an important index of physiological, pathological and nutritional status in the organism (Olorode et al, 2007; Ewuola et al., 2004). Haematological components of blood are also valuable in monitoring feed toxicity especially with feed constituents that affect the formation of blood. Though Aletor (1989) reported that blood variables are most consistently affected by dietary influence including RBC, PVC, and plasma proteins, the results obtained for most haematological parameters examined in this study fall within their normal physiological ranges for rabbits (Jenkins 1993; Mitruka and Rawnsley, 1997). 
It has been reported that normal physiological haematology range for rabbits is; haemoglobin, $8.0-17.5 \mathrm{~g} / \mathrm{dl}$, packed cell volume $(30.00-50.00 \%)$, red blood cell $\left(4.0-8.0 \times 10^{6} / \mathrm{ml}\right)$, white blood cell $\left(5.0-12.0 \times 10^{3} / \mathrm{dl}\right)$, eosinophils (0.0 - 0.5\%) and monocyte (2.0 - 16.0\%) (Hillyer, 1994; Mitruka and Rawnsley, 1994).

A lower level of White blood cell (WBC) was observed in animals fed Alchornea cordifolia leaf meal (ACLM) in $\mathrm{T}_{2}$ group which could be an indication of allergic conditions, anaphylatic shock and certain parasitism as also noted by Ahamepile et al, (2008). It could also be as a result of intake of phytochemicals like Flavonoids, alkaloids and tannin present in the diets. Lymphocyte level was however high which indicates that the rabbits immune systems were challenged by antigen (toxin) probably as antinutritional factors from the diet which interfere with the digestion of dietary proteins and carbohydrates. Another antinutritional factor present in Alchornea cordifolia is saponin and its known to be haemolytic to red blood cells although not harmful but alters the permeability of cell membranes and produce toxic effect on organized tissues when ingested.

Values for Neutrophils (14.00 - 26.50\%) and Basophils (0.00-1.00\%) observed in this study (Table 4) are lower compared to values reported by Jenkins (1993) and Hillyer (1994) as neutrophils (35.00-55.00\%) and Basophils $(2.00-8.00 \%)$. This could be attributed to allergic reaction and/or bacterial or viral infections. It could be as a result of the abnormal increase in percentage lymphocytes as it has been known that an abnormal increase in one type of white blood cell can cause a decrease in the percentage of another types of white blood cells.

Among the treatment diets, PVC, $\mathrm{Hb}, \mathrm{RBC}, \mathrm{WBC}$ and lymphocyte values were highest in $\mathrm{T}_{3}$ (PLM diet). This is attributed to the chemical and nutritional components contained in pawpaw leaves. Pawpaw leaf is reported to be rich in $\mathrm{Ca}, \mathrm{Mg}, \mathrm{Na}, \mathrm{K}, \mathrm{Fe}$, which are useful in the coagulation of blood, proper functioning of the heart and nervous system, useful as both antiseptic and a tonic or blood purifier, as well as the normal contraction of muscles (Atta, 1999). The Sodium content helps to combat stomach acidity and alkalize the blood while iron and Manganese signifies its use against anaemia (Claude and Paule, 1979).

It was observed that values for neutrophils, eosinophils, basophils, and monocytes were highest in animals, fed ACLM $\left(\mathrm{T}_{2}\right)$. This may be as a result of the antimicrobial properties present in the plant as extract of the leaves of Alchornea cordifolia. This has been reported to inhibit the growth of bacteria as staphylococcus aureus., S. albus, Escherichia coli, Bacillus sp and pseudomonas aeruginosa (Ebi, 2001). It is however observed that similarities existed in the values of parameters considered among animals in the control group $\left(\mathrm{T}_{1}\right)$ and those in the group fed 50:50 mixture of ACLM and PLM $\left(\mathrm{T}_{4}\right)$. From the foregoing discussion, it is noted that these two popular plants (Pawpaw and Alchornea cordifolia) does not indicate any deliterous effects on the haematological components of rabbits fed their leaf meals within the levels fed them in the context of this study. Therefore, their inclusion in/as meals for animals especially rabbits is encouraged and the abundance of these plants in the South-South Nigeria should be advantageously used by livestock farmers.

\section{References}

[1]. Ahamefule, F.O., B.E. Obua, I.A. Ukweni, M.A. Oguike and R.A. Amaka (2008). Haemalotological and biochemical profile of weaner rabbits fed raw or processed pigeon pea seed meal based diets. African J. of Agric. Research 3 (4): 315-319.

[2]. Aletor, V.A. (1989). Effect of varying levels of fish meal substitution with soya been meal on certain serum metabolism. Nig. J. Technology Res. 1:111-114.

[3]. Atta, K.B. (1999). The power of Garlic. Cardiovascular Disease Prevention Association, Buea, Cameroon. P72

[4]. Burkill, H.M. (1985). The useful plants of West Tropical Africa. Royal botanical garden kew (7) 1:200-219.

[5]. Cambell, C.W. (1984). Papaya-tropical fruits and nuts. In: F.W. Martin (ed.). Handbook of tropical crops. CRS press inc. Baca Raton, F1. Pp 246-247.

[6]. Chestwort, J. (2002). Ruminant nutrition. Tropical Agriculturalist. CTA/Macmillan Education, London, UK. Pp120.

[7]. Claude, B. and S. Paule. (1979). The manual of natural living. $1^{\text {st }}$ Ed. Biddles Ltd. Pp98-101.

[8]. Duncan, D.B. (1955). Multiple Range and Multiple F-tests. Biometrics. 11:1-42.

[9]. Ebi, C. (2001). Antimicrobial activities of Alchornea cordifolia. Fitoterapia, 72(1):69-72.

[10]. Ewuola, E.O., O.A. Folayan, E.A. Gbore, A.I. Adenunmi, R.A. Akanji, J.T. Ogunlade and J.A. Adeneje,(2004). Physiological response of growing West Africa dwarf goat fed groundnut shell-based diet as the concentrate supplement. Bowen J. Agric. 1(1): 61-69.

[11]. Hillyer, E.V. (1994). Rabbits. Small Anim, Pract., 24:25-65

[12]. Ibeawuchi, J.A., and O.A. Fajuyitan (1986). The rabbit industry: A source of meat for human consumption. Nig. Livestock Farmer 6:26-27.

[13]. Iwu, M.M. (1993). Handbook of African Medical Plants. CRC Press Inc. Florida. Pp1

[14]. Jenkins, J.R. (1993). Rabbits. In: Jenkins, J.R. and Brown S.A (eds.) Practitioners Guide to rabbits and Ferrets. American Animal Hospital Association, Lakewood, U.S.A., Pp1-42.

[15]. Mitruka, B.M. and H.M. Rawsley (1997). Clinical Biochemical and Haematological reference values in normal experimental animal. Masson Publ. Co. New York. Pp102-117.

[16]. Okoli, I.C., C.S. Ebere, M.C. Uchegbu, C.A. Udah and I.I. Ibeawuchi (2002). Survey of the diversity of plants utilized for small ruminants feeding in South Eastern Nigeria. Agriculture, Ecosystem and Environment. 8:147-157.

[17]. Olorode, B.R., R.A. adeniran and J.O. Abiola (2007). Effect of graded levels of morninga oleifera seed meal on haematological values and organ weight of broiler chicken. Trop. J. Amin. Sci Vol. 10 (1-2):63-67.

[18]. Poulter, N.H., and J.C. Caygill (1985). Production and utilization of papain-a proteolytic enzyme from Carica papaya L. Trop.Sci, 25:123-137. 
[19]. Shah, M.K., K. Khan, F. Rizvi, M. Siddique and Sadeeq-ur-Rahman (2007). Effect of cypermethrin on clinico-haematological parameters in rabbits. Pak. Vet. J. 27:171-175.

[20]. Sugiyama, Y. and J. Koman (1992). The floral of Bossui; its utilization by chimpanzees and humans. Africa study monographs. 13(3):127-169.

[21]. Yadava U.L., A. Janice, Burris and D. Mc Garry, (1990). Papaya: A potential annual crop under middle Georgia conditions. In: J. Janick and J.E. Simons (Eds.). Advances in New Crops. Timber Press Portland. Pp 364 - 366 